\title{
EHMTI-0365. The effectiveness of health training on improving sleep quality, and reduction of the symptoms of migraine headaches in individuals with multiple sclerosis
}

\author{
N Torabzadeh ${ }^{1 *}$ S Asadnia ${ }^{1}$, F Sepehrian Azar ${ }^{2}$, M Zamanlu ${ }^{3}$, NAVA Mohammadi ${ }^{4}$ \\ From 4th European Headache and Migraine Trust International Congress: EHMTIC 2014 \\ Copenhagen, Denmark. 18-21 September 2014
}

\section{Introduction}

Migraine headaches and undesirable quality of sleep in patients with multiple sclerosis are very common.

\footnotetext{
Aims

The aim of the present study is the effectiveness of sleep health training on improving sleep quality, and reduction of the symptoms of migraine headaches in individuals with multiple sclerosis.
}

\section{Methods}

Therefore, to do this, 60 patients with MS peered selected and randomly put into two groups of experimental and control. They answered Pittsburg quality of sleep of the Najarian symptoms of migraine headache. Experimental group took part for four sessions of Sleep health training session. After completing the sessions both answered to two tests again.

\section{Results}

The results showed that sleep health training on improving the quality of sleep and reduction the symptoms of migraine headache has been effective in experimental group.

\section{Conclusions}

Therefore, sleep health training to improve the quality of sleep and reduce the symptoms of migraine headache sufferers of MS, can be conducted along with other pharmaceutical and medical treatments.

\footnotetext{
${ }^{1}$ Psychology Department, Urmia University of Medical Sciences, Urmia, Iran
} Full list of author information is available at the end of the article
No conflict of interest.

\section{Authors' details}

'Psychology Department, Urmia University of Medical Sciences, Urmia, Iran. ${ }^{2}$ Psychology Department, Urmia University, Urmia, Iran. ${ }^{3}$ Psychology Department, Neuroscience Research CenterTabriz University of Medical Sciences, Tabriz, Iran. ${ }^{4}$ Psychology Department, Urmia University, Urmia, Iran.

Published: 18 September 2014

doi:10.1186/1129-2377-15-S1-J14

Cite this article as: Torabzadeh et al: EHMTI-0365. The effectiveness of health training on improving sleep quality, and reduction of the symptoms of migraine headaches in individuals with multiple sclerosis. The Journal of Headache and Pain 2014 15(Suppl 1):J14.

\section{SpringerOpen ${ }^{\circ}$}

๑ 2014 Torabzadeh et al; licensee Springer. This is an Open Access article distributed under the terms of the Creative Commons Attribution License (http://creativecommons.org/licenses/by/2.0), which permits unrestricted use, distribution, and reproduction in any medium, provided the original work is properly cited.
Submit your manuscript to a SpringerOpen ${ }^{\bullet}$ journal and benefit from:

- Convenient online submission

- Rigorous peer review

- Immediate publication on acceptance

- Open access: articles freely available online

- High visibility within the field

- Retaining the copyright to your article

Submit your next manuscript at $>$ springeropen.com 